\title{
Pertumbuhan Benih Ikan Mas (Cyprinus carpio) Pada Media Biofilter Berbeda
}

\author{
[Growth of Carp (Cyprinus carpio) Seed With Different Biofiltering Media]
}

\author{
Sabrina, Samliok Ndobe, Musayyadah Tis'i, Desiana T. Tobigo
}

Program Studi Akuakultur, Fakultas Peternakan dan Perikanan, Universitas Tadulako

Diterima: . 22 November 2018; Disetujui: 20 Desember 2018

\begin{abstract}
Abstrak
Budidaya ikan secara intensif, dengan padat penebaran dan dosis pemberian pakan yang tinggi akan mengakibatkan penurunan kualitas air budidaya, dimana sisa pakan dan sisa metabolisme ikan pada wadah budidaya, akan menghasilkan toksin berupa amonia sehingga dibutuhkan sistem budidaya yang dapat mereduksi toksin. Akuaponik merupakan salah satu sistem budidaya yang mampu mereduksi toksin di perairan dengan cara mempertahankan kualitas air selama periode tertentu tanpa mengganggu pertumbuhan ikan yang dipelihara dengan menggunakan tanaman sebagai biofilter. Tanaman akuaponik yang sering digunakan pembudidaya adalah tanaman yang memiliki akar serabut, antara lain kangkung air, sawi, selada. Jenis-jenis tanaman tersebut dapat memanfaatkan unsur hara yang ada dalam air media budidaya dari hasil buangan bahan organik oleh bakteri nitrifikasi berupa nitrat untuk pertumbuhan tanaman yang dibudidayakan. Adapun jenis ikan yang sering digunakan dalam sistem akuaponik adalah ikan mas, nila, lele, bawal dan patin. Ikan mas (Cyprinus carpio L.) pada saat ini merupakan ikan air tawar yang paling tinggi produksinya dan sudah dibudidayakan secara komersil. Penelitian telah dilakukan untuk mengetahui pertumbuhan ikan mas ( $C$. carpio) pada media biofilter dengan menggunakan jenis tanaman berbeda. Ikan mas yang digunakan dalam penelitian berukuran 5 $7 \mathrm{~cm}$. Penelitian didesain dengan menggunakan pola rancangan acak lengkap (RAL) 4 perlakuan (sebagai biofilter, yaitu tanaman sawi, kangkung, selada dan tanpa tanaman sebagai kontrol. Semua perlakuan diulang sebanyak 5 kali. Hasil penelitian menunjukan bahwa penggunaan biofilter tanaman sawi memberikan pertumbuhan bobot mutlak tertinggi pada ikan mas.
\end{abstract}

Kata kunci : biofilter; ikan mas; pertumbuhan

\section{Abstract}

Intensive aquaculture, with high stocking densities and feed dosages, can lead to poor water quality. Left-over feed and metabolic waste products can produce toxic compounds, in particular ammonia. Therefore there is a need for aquaculture systems which can reduce toxin levels. Aquaponics are one approach to water quality maintenance in aquaculture, and can reduce toxin levels over certain periods of time without interfering with the growth of cultured fish, through the use of plants as biofiltering media. Plants used by fish-farmers in aquaponic systems generally have fibrous roots, e.g. water spinach, Chinese mustard, and lettuce. These plants can make use of the nutrients released into the culture medium (water) as nitrates by nitrifying bacteria. Fish which are frequently reared in aquaponic systems include carp, tilapia, catfish, pacu, and pangasius. Currently, carp (Cyprinus carpio L.) are the commercially cultured freshwater fish with the highest production volume. This research aimed to compare the growth of carp (C. carpio) seed cultured with biofiltration using different plants. The experimental animals were carp seed with an initial length of $5-7 \mathrm{~cm}$. The research used a fully randomised design with 4 treatments, 3 with biofiltering plants (Chinese mustard, water spinach, lettuce) and a control with no plants. All treatments had 5 replicates. The results showed that the net weight gain of the carp seed was highest under the biofiltration treatment using Chinese mustard.

Keywords: biofiltration; carp; growth 


\section{PENDAHULUAN}

Budidaya ikan secara intensif, dengan padat penebaran dan dosis pemberian pakan yang tinggi akan mengakibatkan penurunan kualitas air budidaya, dimana sisa pakan dan sisa metabolisme ikan pada wadah budidaya, akan menghasilkan toksin berupa amonia (Samsundari dan Wirawan, 2013). Sistem yang baik untuk mereduksi toksin berupa amonia yakni sistem akuponik. Sistem ini menggunakan tanaman yang mampu mereduksi toksin yang ada di perairan, sistem ini juga memberikan hasil sampingan berupa sayuran dan ikan (Nugroho, 2008 dalam Muhammad dkk., 2016).

Sagita dkk., (2014) dalam Wicaksana dkk. (2015) menyatakan sistem akuaponik merupakan sistem pada teknik budidaya yang mempertahankan kualitas air selama periode tertentu tanpa mengganggu pertumbuhan ikan yang dipadukan dengan sistem tanaman akuatik. Selain itu sistem ini mampu menyerap limbah budidaya berupa sisa pakan maupun feses oleh tanaman akuaponik. Menurut Ornes dan Sajwan (1993) dalam Dwiyanti dan Gunadi (2006), tanaman akuaponik yang sering digunakan pembudidaya adalah tanaman yang memiliki akar serabut, tanaman tersebut contohnya kangkung air, sawi dan selada. Tanaman air dapat memanfaatkan unsur hara yang ada dalam air media budidaya dari hasil buangan bahan organik oleh bakteri nitrifikasi berupa nitrat untuk pertumbuhan tanaman yang di budidayakan. Adapun jenis ikan yang sering digunakan dalam sistem akuaponik adalah ikan mas, nila, lele, bawal dan patin. Ikan mas (Cyprinus carpio L.) pada saat ini merupakan ikan air tawar yang paling tinggi produksinya dan sudah dibudidayakan secara komersil di seluruh propinsi di Indonesia (Pudjirahaju dkk., 2008). Ikan ini memiliki toleransi yang sangat tinggi terhadap lingkungan sekitarnya (Silaban $d k k$., 2012). Oleh sebab itu perlu dilakukan penelitian tentang pengaruh penggunaan tanaman air yang berbeda dengan media biofilter terhadap pertumbuhan benih ikan mas (Cyprinus carpio L.). Tujuan penelitian adalah untuk mengetahui pengaruh penggunaan media biofilter berbeda terhadap pertumbuhan benih ikan mas (Cyprinus carpio L.). 
BAHAN DAN METODE

Organisme uji yang digunakan adalah ikan mas (Ciprinus carpio) berukuran 5-7 cm sebanyak 80 ekor yang diperoleh dari Balai Benih Ikan (BBI) Kabupaten sigi, Sulawesi Tengah. Eksperimen dilaksanakan pada bulan November-Desember 2017, Di Laboratorium Program Studi Akuakultur, Fakultas Peternakan dan Perikanan, Universitas Tadulako.

Benih ikan mas sebelum diberi perlakuan terlebih dahulu diaklimatisasi dengan lingkungan dan pakan selama 5 hari. Benih ikan mas yang ditebar dengan kepadatan 1 ekor/3 liter air, dipelihara dalam wadah pemeliharan dengan padat tebar 5 ekor/wadah. Benih ikan mas diberi pakan pellet apung sebanyak 5\% dari bobot badan. Penelitian didesign dengan pola Rancangan Acak Lengkap (RAL) yang terdiri dari 4 perlakuan (penggunaan biofilter sawi, kangkung, selada dan tanpa biofilter), setiap perlakuan diulang sebanyak 5 kali.

Pengamatan petumbuhan dengan mengukuran bobot dan panjang yang dilakukan setiap 10 hari sekali. Analisa pertumbuhan bobot mutlak ikan mas dilakukan dengan menggunakan persamaan berikut:

$$
\mathrm{G}=\overline{\mathrm{W}} \mathrm{t}-\overline{\mathrm{W}} \mathrm{o}
$$

Keterangan :

$\mathrm{G}=$ Bobot mutlak $(\mathrm{g})$
$\overline{\mathrm{W}} \mathrm{t}=$ Rata-rata bobot pada akhir penelitian $(\mathrm{g})$

$\overline{\mathrm{W}} \mathrm{o}=$ Rata-rata bobot pada awal penelitian $(\mathrm{g})$

Pertumbuhan panjang mutlak ikan mas dilakukan dengan menggunakan persamaan berikut:

$$
\mathrm{L}=\overline{\mathrm{W}} \mathrm{t}-\overline{\mathrm{W}} \mathrm{o}
$$

Keterangan :

$\mathrm{L}=\quad$ Bobot mutlak $(\mathrm{g})$

Lt = Rata-rata bobot pada akhir penelitian $(\mathrm{g})$

Lo = Rata-rata bobot pada awal penelitian $(\mathrm{g})$

Sintasan atau kelangsungan hidup (SR) adalah perbandingan jumlah ikan yang hidup dengan ikan pada awal pemeliharaan :

$$
\mathrm{SR}=\frac{\mathrm{Nt}}{\mathrm{No}} \times 100 \%
$$

Keterangan :

$\mathrm{SR}=$ Survival rate (Kelangsungan hidup) (\%)

$\mathrm{Nt}=$ Jumlah benih di akhir pemeliharaan (ekor)

No = Jumlah benih di awal pemeliharaan (ekor)

Parameter kualitas air yang diamati meliputi suhu, oksigen terlarut (DO), $\mathrm{pH}$ dan amonia. 


\section{HASIL DAN PEMBAHASAN}

Hasil pengamatan pertumbuhan ikan mas dengan menggunakan biofilter berbeda tidak berpengaruh nyata. Data pertumbuhan bobot mutlak $C$. carpio (Gambar 1) yang diperoleh selama penelitian berkisar 1,28-1,78 g. Pertumbuhan bobot mutlak tertinggi selama penelitian terdapat pada perlakuan biofilter dengan menggunakan tanaman sawi (Perlakuan A).

Data pertumbuhan panjang mutlak ikan mas (Gambar 2) yang diperoleh selama penelitian berkisar 1,09-1,30 cm. Pertumbuhan panjang mutlak tertinggi selama penelitian terdapat pada perlakuan biofilter dengan menggunakan biofilter tanaman sawi (Perlakuan A) dan biofilter tanaman kangkung (Perlakuan B) dengan panjang mutlak sama yaitu $1,30 \mathrm{~cm}$.

Hasil rata-rata kelangsungan hidup atau sintasan ikan mas pada masing perlakuan tertera pada Gambar 7. Sintasan yang tinggi diperoleh pada perlakuan biofilter tanaman sawi $(\mathrm{A})$ dan

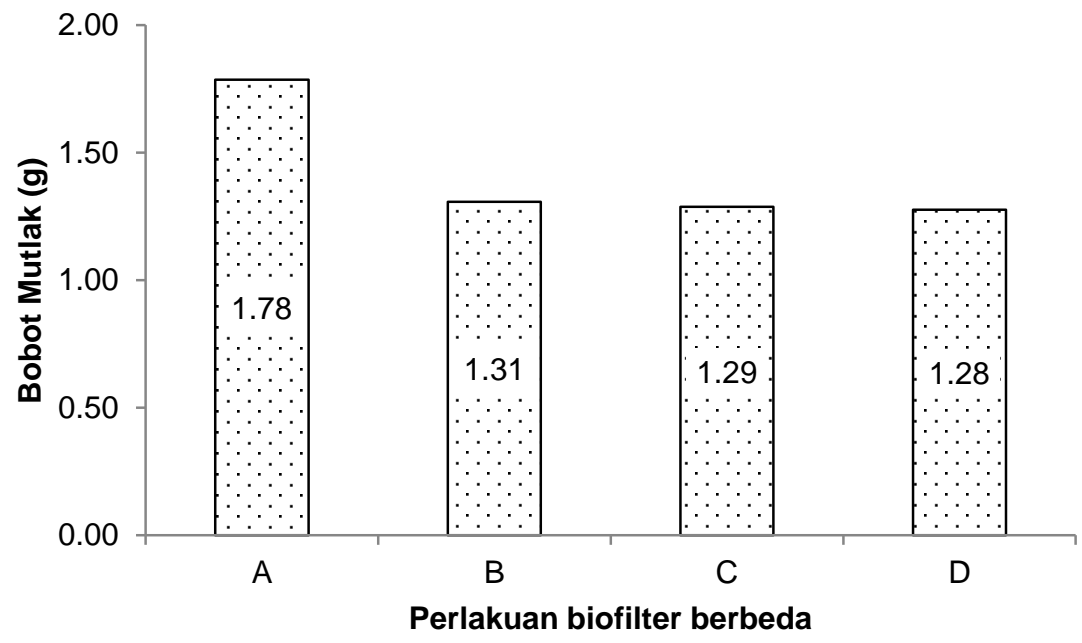

Gambar 1. Pertumbuhan bobot mutlak ikan mas (Cyprinus carpio)

Tabel 1. Kualitas air selama penelitian

\begin{tabular}{lcccccc}
\hline & \multicolumn{6}{c}{ Kisaran parameter kualitas air } \\
\cline { 2 - 7 } Perlakuan & Suhu $\left({ }^{\circ} \mathbf{C}\right)$ & pH & DO $(\mathbf{M g} / \mathbf{l})$ & \multicolumn{3}{c}{ Amonia $\left(\mathbf{N H}_{3}\right)(\mathbf{M g} / \mathbf{l})$} \\
\cline { 2 - 7 } & & & & Awal & Tengah & Akhir \\
\hline A & $27-28$ & $8,4-8,9$ & $6,4-7,0$ & 0,0016 & 0,0021 & 0,0023 \\
B & $26-28$ & $8,4-8,7$ & $6,3-7,1$ & 0,0015 & 0,0020 & 0,0023 \\
C & $26-28$ & $8,5-8,8$ & $6,2-6,9$ & 0,0017 & 0,0021 & 0,0024 \\
D & $26-28$ & $8.4-8.7$ & $5,9-7,0$ & 0,0017 & 0,0023 & 0,0026 \\
\hline
\end{tabular}




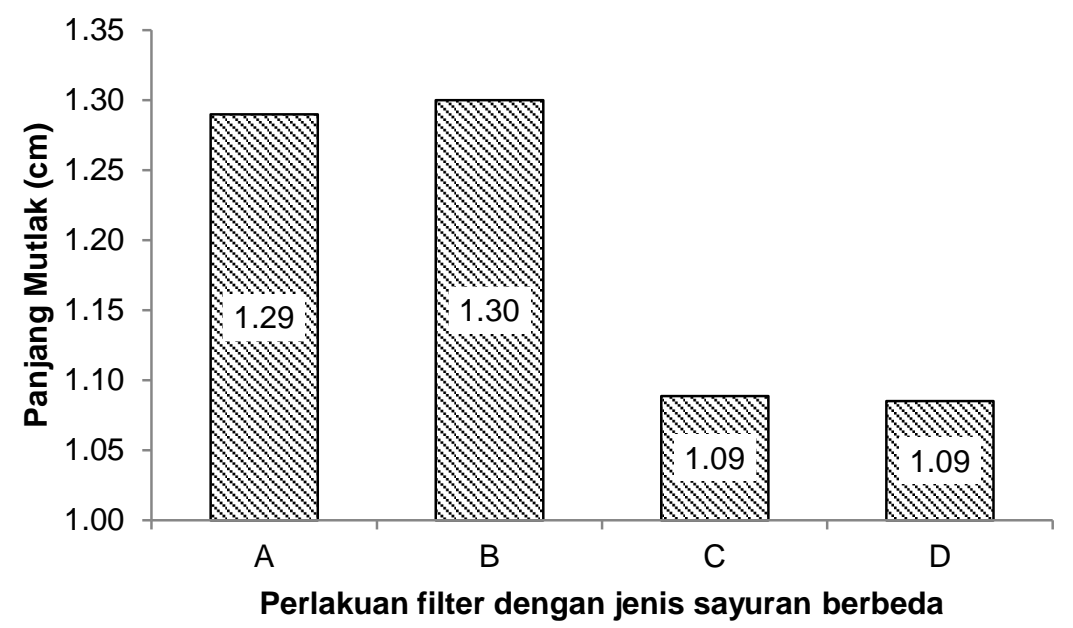

Gambar 2. Pertumbuhan panjang mutlak ikan mas (Cyprinus carpio)

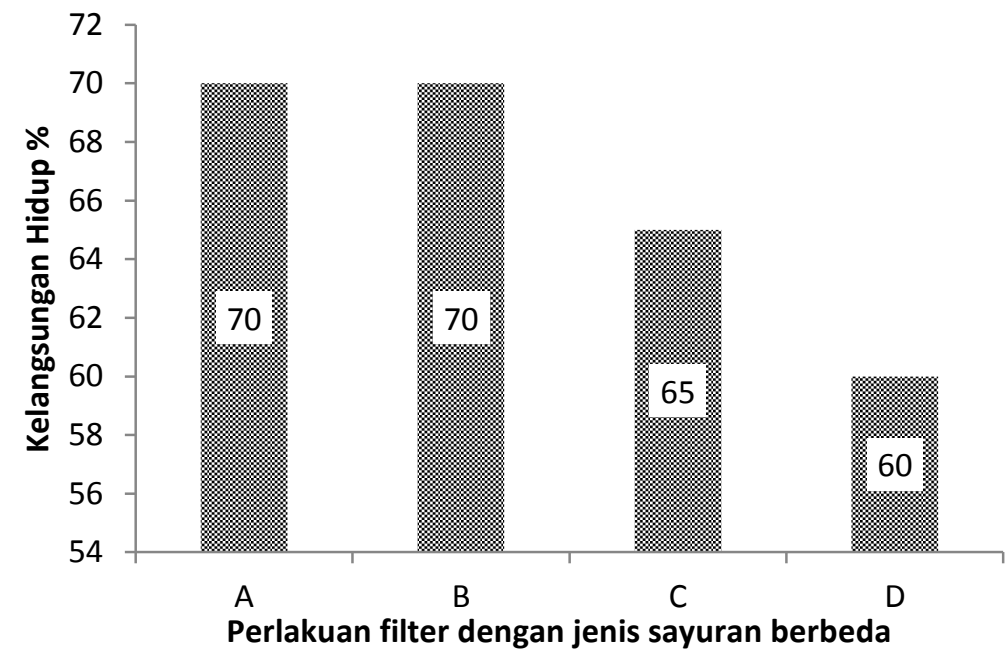

Gambar 3. Sintasan benih ikan mas (Cyprinus carpio)

biofilter tanaman kangkung (B), yaitu berbeda tidak berpengaruh nyata masing-masing sebesar $70 \%)$, diikuti $(\mathrm{P}>0,05)$ terhadap pertumbuhan bobot pada perlakuan biofilter tanaman mutlak benih ikan mas (C. carpio). Hal ini kangkung (C), yaitu $65 \%$, dan perlakuan menunjukkan bahwa penggunaan tanpa biofilter (D), yaitu $50 \%$.

Adapun data hasil pengukuran biofilter dengan menggunakan jenis-jenis tanaman memberikan pengaruh kualitas air yang dilakukan selama pertumbuhan yang sama. Mulqan $d k k$. penelitian tertera pada Tabel 1.

(2017) menyatakan bahwa sawi,

Hasil analisis sidik ragam (ANOVA) kangkung dan selada memiliki menunjukkan media biofilter dengan kemampuan yang sama dalam proses menggunakan jenis tanaman yang resirkulasi air dalam media pemeliharaan 
ikan, serta diduga terjadinya proses filterisasi yang optimal (pada penggunaan sawi, kangkung dan selada dalam media biofilter) sehingga menghasilkan kualitas air yang baik di dalam media pemeliharaan ikan yang mendukung proses pertumbuhan ikan.

Pertumbuhan bobot mutlak yang terdapat pada perlakuan biofilter dengan menggunakan tanaman kangkung (Perlakuan B), tanaman selada (Perlakuan C) dan tanpa tanaman (Perlakuan D) memiliki nilai pertumbuhan yang hampir sama (Gambar 1). Tingginya pertumbuhan bobot mutlak yang terdapat pada perlakuan biofilter dengan menggunakan tanaman sawi (Perlakuan A) diduga karena sawi memiliki akar serabut lebih mudah memfilter dan menyerap bahan organic dibandingkan dengan tanaman kangkung dan selada, sehingga kadar tosin dalam wadah pemeliharaan dapat dinetralisir, yang menyebabkan organisme uji dapat mengkonsumsi pakan dengan baik. Haryadi (2010) dalam Tambunan dkk. (2013) menyatakan bahwa tanaman sawi mampu menyerap bahan organik khususnya nitrogen. Sawi juga mampu menekan cemaran yang terdapat pada air parameter yang mampu dipulihkan antara lain kandungan bahan organik, karena tanaman sawi mampu menyaring partikel yang ada di air.
Demikian pula hasil analisis ragam (ANOVA) menunjukkan media biofilter dengan menggunakan jenis tanaman yang berbeda tidak berpengaruh nyata $(\mathrm{P}>0,05)$ terhadap pertumbuhan panjang mutlak benih ikan mas (C. carpio). Ratarata pertumbuhan panjang mutlak tertinggi terdapat pada perlakuan biofilter dengan menggunakan biofilter tanaman sawi (Perlakuan A) dan biofilter tanaman kangkung (Perlakuan B).

Hasil pengukuran pertumbuhan panjang mutlak yang dipelihara dengan media biofilter pada akhir penelitian mengalami peningkatan. Data pertumbuhan panjang mutlak terbaik terdapat pada perlakuan biofilter dengan menggunakan biofilter tanaman kangkung (Perlakuan B) tidak berbeda jauh antara perlakuan biofilter dengan menggunakan biofilter tanaman sawi (Perlakuan A), sedangkan untuk perlakuan yang terendah terdapat pada perlakuan biofilter tanaman selada (Perlakuan C) dan tanpa biofilter (Perlakuan D) (Gambar 2). Hal ini sesuai dengan hasil penelitian Samsundari dan wirawan (2013), menyatakan bahwa jenis biofilter yang baik untuk pertumbuhan dan kualitas air yakni tanaman sawi. Haryadi (2010) dalam Tambunan dkk. (2013) menyatakan bahwa tanaman sawi mampu menyerap bahan organik khususnya nitrogen yang ada di perairan. 
Hasil penelitian menunjukkan bahwa perlakuan A dan B memiliki tingkat kelangsungan hidup yg lebih tinggi dibandingkan dengan $C$ dan $D$ (Gambar 3). Selama penelitian kematian ikan mas terjadi pada awal penelitian. Hal ini diduga respon adaptasi terhadap lingkungan dan perlakuan. Menurut Effendi (1979) dalam mulyadi dkk. (2014) faktor yang mempengaruhi tinggi rendahnya kelangsungan hidup adalah faktor abiotik dan biotik, antara lain kualitas air, kompetitor, kepadatan populasi, umur dan kemampuan organisme beradaptasi dengan lingkungan. Sejalan dengan pernyataan Weartherley (1972) dalam mulyadi dkk. (2014) yang menyatakan bahwa kematian ikan dapat terjadi disebabkan oleh predator, parasit, penyakit, populasi, keadaan lingkungan yang tidak cocok.

Kisaran kualitas air dari awal hingga akhir penelitian menunjukkan bahwa parameter masih dalam batas kelayakan untuk kehidupan benih ikan mas (Tabel 1). Hasil pengukuran nilai suhu pada media pemeliharaan benih ikan mas yang diperoleh selama penelitian berkisar antara $26-28{ }^{\circ} \mathrm{C}$, kisaran ini masih mendukung pertumbuhan dan kelangsungan hidup benih C. carpio. Hal ini sesuai dengan penelitian Effendi dkk. (2015) menyatakan suhu $25-32 \stackrel{\circ}{\circ}$. layak untuk pertumbuhan ikan. Menurut Effendi
(2003), perubahan suhu berpengaruh terhadap proses fisika, kimia dan biologi badan air. Selain itu, peningkatan suhu juga dapat meningkatkan kecepatan metabolisme dan respirasi organisme akuatik, dan selanjutnya mengakibatkan konsumsi oksigen meningkat. Namun, peningkatan suhu ini disertai dengan penurunan kandungan oksigen terlarut, sehingga keberadaan oksigen seringkali tidak mampu memenuhi kebutuhan oksigen bagi organisme akuatik untuk melakukan proses metabolisme dan respirasi. Hal ini mengakibatkan pertumbuhan dan kelangsungan hidup ikan terganggu.

Data hasil pengukuran $\mathrm{pH}$ selama penelitian menunjukkan kisaran antara 8,4-8,9 (Tabel 1). Nilai tersebut masih dalam kisaran yang dapat ditoleransi untuk pemeliharaan benih ikan mas, sesuai pernyataan Kodri dan Tancung (2007) dalam Saptarini (2010) nilai pH yang baik untuk budidaya berkisar antara 6,6-9,0 (Tabel 1). Nilai pH yang yang tinggi (>9) akan mengakibatkan pertumbuhan ikan akan terhambat sedangkan $\mathrm{pH}$ yang rendah $(<4,5-6,5)$ menyebabkan kualitas air akan menjadi racun bagi ikan, mengalami pertumbuhan terhambat dan ikan akan menjadi sensitif dengan terhadap bakteri dan parasite.

Oksigen terlarut merupakan faktor yang penting dalam kehidupan ikan. 
Kandungan oksigen terlalur (DO) berkisar antara 6,2-7,1 (Tabel 1) merupakan kandungan oksigen yang layak untuk pertumbuhan benih ikan mas. Hal tersebut sesuai dengan pernyatan dari Irianto (2005) dalam Saptarini (2010), pada dasarnya konsentrasi oksigen yang terlarut $5 \mathrm{mg} \mathrm{L}$ 1 merupakan kandungan oksigen yang dianjurkan untuk pembudidaya. Saptarini (2010), menyatakan apabila kandungan oksigen terlalu turun berkisar antara 3-4 $\mathrm{Mg} \mathrm{L}^{-1}$ ikan akan mengalami stress dan akan mengalami mortalitas.

Kadar amonia pada setiap perlakuan memiliki nilai yang layak untuk kegiatan budidaya ikan. Konsentrasi amonia selama penelitian adalah 0,0015-0,0019 $\mathrm{mg} \mathrm{L}^{-1}$.

Sedangkan konsentrasi amoniak akhir penelitian berkisar antara 0,00230,0026 $\left.\mathrm{mg} \mathrm{L}^{-1}\right)$. konsentrasi amonia terendah pada akhir penelitian terdapat pada perlakuan A (biofilter tanaman sawi) dan perlakuan B (biofilter tanaman kangkung) dengan kadar 0,0023 $\mathrm{mg} \mathrm{L}^{-1}$, selanjutnya pada perlakuan C (biofilter tanaman selada) $0,0024 \mathrm{mg} \mathrm{L-1}$, sedangkan konsentrasi amonia yang tertinggi pada perlakuan D (tanpa biofilter) $0,0026 \mathrm{mg} \mathrm{L}^{-1}$ (Tabel 1). Hal ini sesuai penelitian dari Dauhan $d k k$ (2014), bahwa penyerap amonia sangat optimal dimanfaatkan oleh tanaman kangkung untuk pertumbuhan.
Rendahnya kadar amonia dengan menggunakan tanaman kangkung diduga karena akar tanaman kangkung lebih berserabut dan lebih panjang dibandingkan dengan tanaman sawi dan selada.

\section{KESIMPULAN}

Berdasarkan penelitian yang telah dilakukan, maka dapat disimpulkan beberapa hal sebagai berikut:

1. Penggunaan biofilter terhadap pertumbuhan bobot maupun panjang mutlak benih ikan mas (Cyrinus carpio) tidak berpengaruh nyata $(P>0,005)$,

2. Penggunaan tanaman sawi sebagai biofilter memberikan pertumbuhan terbaik pada ikan mas.

3. Kelangsungan hidup terbaik benih ikan mas pada perlakuan penggunaan biofilter tanaman sawi dan kanngkung.

4. Kualitas air pada semua perlakuan secara umum masih berada dalam batas toleransi untuk pertumbuhan ikan dan tidak berbahaya pada pertumbuhan ikan mas.

\section{DAFTAR PUSTAKA}

Dauhan R. E. S, E. Efendi. Suparmono. 2014. Efektifitas media biofilter dalam mereduksi konsentrasi amonia pada sistem budidaya ikan. 
Jurnal rekayasa dan teknologi budidaya perairan. 3 (1) : 297-302.

Dwiyanti, D.S., B. Gunadi. 2006. Efektivitas Biofilter Tanaman Air Terhadap Pengolahan Limbah Budidaya Ikan dengan Sistem Resirkulasi. Seminar Nasional Limnologi, Widya Graha LIPI. Jakarta.

Effendi H. 2003. Telah kualitas air bagi pengelolaan sumberdaya dan lingkungan perairan. Kanisius. Yogyakarta.

Effendi, H., B.A Utomo, G.M Darmawangsa, R.E Karo-karo. 2015. Fitoremediasi limbah budidaya ikan lele (Clarias sp.) dengan kangkung (Ipomea aquatica) dan pakcoy (Brassica rapa chinensis) dalam sistem resirkulasi. Ecolab, 9 (2) : 47-104.

Margono, E. M., Sumoharjo, Ma'ruf, M. 2014. Studi Potensi Kiambang (Limna minor) sebagai Organisme Biofilter dalam Sitem Akuakultur. Jurnal IImu Perikanan Tropis, 20 (1) : 25-33.

Muhammad, F., M., Hastuti., Sarjito. 2016. Pengaruh Sistem Biofilter Akuaponik terhadap Profil Darah, Histologi Hati dan Kelulushidupan pada Ikan Lele (Clarias gariepenus). Journal of
Aquaculture Management and Technology, 5 (1) : 64-72.

Mulqan, M., Sayyis A., E., R., Irma D. 2017. Pertumbuhan dan kelangsungan hidup benih ikan Nila Gesit (Oreochromis nilaticus) pada media biofilter dengan jenis tanaman yang berbeda. Jurnal IImiah Mahasiswa Kelauta dan Perikanan. Universitas Syiah Kuala Darussalam. Jurnal 2 (1) : 183-193. Mulyadi, Tang, U., dan Yani, E. S. 2014. Sitem resirkulasi dengan menggunakan filter yang berdeda terhadap pertumbuhan benih ikan nila (Oreochromis nilaticus). Jurnal Akuakultur Rawa landonesia. 2(2) :117-124.

Ndobe S. 2010. Struktur ukuran glass eel ikan sidat (Anguilla marmorata) di muara Sungai Palu, Kota Palu, Sulawesi Tengah. Media Litbang Sulteng III (2): 144 - 150.

Ndobe S., Madinawati, Serdiati N., Syukri dan Moore A. 2017. Pertumbuhan benih ikan gabus Channa striata dengan pakan cacing darah beku. Jurnal Sains Teknologi Akuakultur (2017) 1 (2): 104-110.

Ndobe S., Serdiati N., Moore A. 2013. Upaya domestikasi melalui pembesaran ikan gabus (Channa striata) di dalam wadah terkontrol. 
Prosiding Konferensi Akuakultur Indonesia 2013: 165-175.

Pudjirahaju, A., Rustidja, dan Sumitro, S., B. 2008. Penelusuran Genotipe Ikan Mas (Cyprinus carpio L.) Strain Punten Gynogenetik. Jurnal Ilmu-ilmu Perairan dan Perikanan Indonesia, $1:$ 13-19.

Rosita, E., W.R. Melani, A. Zulfikar. 2013. Efektivita Fitoremediasi Kangkung Air (Ipomoea Aquatic Forks) Terhadap Penyerapan Orthopospat pada Detergen Ditinjau dari Detensi Waktu Dan Konsentarasi Orthopospat.

Samsundari, S., Wirawan, G., A. 2013. Analisis Penerapan Biofilter Sistem Resirkulasi Terhadap Mutu Kualitas Air Budidaya Ikan Sidat (Anguila bicolor). Jurnal Gama, 8 (2) : 86-97.

Saptarini, P. 2010. Efektifitas teknik akuaponik dengan kangkung darat (Ipomoea reptans ) terhadap penurunan ammonia pada pembesaran ikan mas. Skripsi. Fakultas Perikanan dan IImu Kelautan, Institut Pertanian Bogor. Bogor.

Setijaningsih, L., Suryaningrum. 2015. Pemanfaatan Limbah Budidaya Ikan Lele (Clarias batrachus) Untuk Ikan Nila (Oreocromis nilotucus) dengan Sistem Resirkulasi. Berita Biologi. 14(3) : 287- 293.

Silaban, T, F., Santoso, L., dan Suparmono. 2012. Dalam Peningkatkan Kinerja Filter Air untuk Menurunkann Konsentrasi Amonia pada Pemeliharaan Ikan Mas (Cyprinus carpio L.). Jurnal Rekayasa san Teknologi Budidaya Perairan. 1(1) : 47-56.

Tambunan, E.P., U.M. Tang, dan Mulyadi, 2013. Cultivation of River Catfish (Mystus nemurus C.V) in Aquaponic Resirculation System with The Addition of $\mathrm{EM}_{4}$.

Wicaksana, S., N., Hastuti, S., Arini, E. 2015. Performa Produksi Ikan Lele Domno (Clarias gariepinus) Yang Dipelihara dengan Sistem Biofilter Akuapomik dan Konvensional. Jurnal of Aquaculture Management and Technology, 4 (4) : 109-116. 